\title{
Overview of US incubators and the case of the Austin Technology Incubator
}

\section{Joel Wiggins and David V. Gibson}

\author{
Austin Technology Incubator, IC2 Institute, \\ The University of Texas at Austin, 3925 W. Braker Lane, \\ Austin, TX 78759, USA \\ E-mail: jwiggins@ati.utexas.edu E-mail: davidg@icc.utexas.edu
}

\begin{abstract}
Business incubators have a 25-year history in the US. Today they number more than 800 . Most are non-profit entities, many associated with universities. This article provides a general overview of business incubation in the US and provides a case study of the award-winning Austin Technology Incubator whose companies have generated over $\$ 1.4$ billion in revenues and created some 3,000 jobs. The authors conclude that business incubators must accomplish five tasks well in order to succeed: (1) establish clear metrics for success; (2) provide entrepreneurial leadership; (3) develop and deliver valueadded services to member companies; (4) develop a rational new-company selection process; and (5) ensure that member companies gain access to necessary human and financial resources.
\end{abstract}

Keywords: Incubator; accelerator; Austin; technology; business.

Reference to this paper should be made as follows: Wiggins, J. and Gibson, D.V. (2003) 'Overview of US incubators and the case of the Austin Technology Incubator', Int. J. Entrepreneurship and Innovation Management, Vol. 3, Nos. 1/2, pp.56-66.

Biographical notes: Joel Wiggins serves as the Director of the Austin Technology Incubator at the IC ${ }^{2}$ Institute at The University of Texas at Austin. Dr. Wiggins' current responsibilities include all aspects of incubator operations, planning, expansion, company recruitment and staff management. $\mathrm{He}$ also provides strategic direction in making the Incubator an 'experiential learning laboratory' where students, faculty, and global researchers can study high-tech entrepreneurship. Dr. Wiggins has also directed the student development programs of the incubators, coordinated the Institute's community relation activities in the university and local communities, and provided consulting services for the ATI companies. Dr. Wiggins holds a PhD in Communication from The University of Texas at Austin where he received numerous awards including a University Fellowship and the Jesse H. Jones Endowed Centennial Fellowship from the College of Communication.

David V. Gibson is Director, Research and The Nadya Kozmetsky Scott Centennial Fellow, at the IC $^{2}$ [Innovation, Creativity, Capital] Institute, The University of Texas at Austin. In 1983, he earned his PhD from Stanford in organisational behaviour and communication theory. Dr. Gibson's research and publications focus on the strategic management of knowledge; cross-cultural communication; the management and commercialisation of technology; and the growth and impact of regional technology centres on knowledge/technology transfer and adoption, technology incubator operations, and the formation and management of global alliances. 


\section{Introduction}

US incubators, as we now know them, came into being in the USA during the 1970s-although the first began in an abandoned Massey Ferguson manufacturing plant in Batavia, New York in 1959. "Other plants had closed before Massey Ferguson, but this was the killer," says Joe Mancuso who bought the $850,000 \mathrm{ft}^{2}$ complex-broken windows, leaking roofs, and boarded up doors notwithstanding. Well over 3,000 jobs later, the incubator continues to serve as an anchor to the region's economy.

The early incubators evolved from three concurrent forces. The first was an attempt to put to use old, unoccupied manufacturing buildings in distressed Midwest and Northeast communities by subdividing them for small businesses. The second force came from the National Science Foundation that funded emerging university programs in innovation and entrepreneurship. The third driver consisted of individual or groups of successful entrepreneurs that sought to transfer their experience to, and invest their resources in, new technology companies.

However, by 1980 there were only 12 business incubators in the USA and between 1984 and 1987, the US Small Business Administration undertook a number of initiatives to strengthen the incubation movement. The agency held regional conferences to introduce the incubator concept to various regions of the country; it published newsletters and handbooks on incubation; and, most importantly, supported the formation of the National Business Incubation Association (NBIA) in 1985. As the leading association of incubator professionals in the world, the NBIA membership has grown from 40 to over 1100 during the past 16 years. Between 1985 and 1995 the number of incubators in the USA grew 15-fold, from 40 to nearly 600-and today there are some 850 incubators.

The earliest incubators focused their efforts on new technologies, light manufacturing, and services. However, as the industry has matured the types of businesses incubated has significantly broadened. Incubation is a highly adaptable business intervention form, and today's incubators target diverse industries such as biotechnology, clean energy, ceramics technologies, the internet, software and telecommunications, high technology, and the arts. The industry services high-growth, venture-backed businesses as well as micro enterprises; women and minority owned businesses; and rural, suburban and urban environments [1].

In the USA, approximately $75 \%$ of all incubators are non-profitmaking entities that are supported by local governments, academic institutions of higher learning, and/or local businesses. In 1998, a report issued by the NBIA placed that number at more than $90 \%$. However, during the .com mania there was a pronounced shift towards for-profit incubators. Between August 1999 and August 2000, for example, it is estimated that in the USA, a for-profit internet incubator was being created every other day. Aberdeen Group analyst Dave Wright estimates that the number of for-profit incubators rose from just 37 in January 1998 to more than 400 by July 2000. Seeking to capitalise on the new economy and walk in the footsteps of Bill Gross' Idealabs!, these incubators (a.k.a. 'hatcheries,' 'eco-nets,' 'greenhouses,') raised impressive sums of venture capital. Idealabs! raised more than a billion dollars and divine interVentures garnered more than $\$ 600$ million before its nine-times postponed and disappointing IPO in July 2000. However, the decline of the public markets that began in March 2000 signalled the demise of many of these internet incubators. Wright predicts that only 150 of them will be conducting any business by 2003. It must be noted, however, that if Wright is right, the growth in for-profit incubators will still be $4 \mathrm{x}$ in five years (1998-2003). Table 1 
illustrates the precipitous fall of some of the most well known and publicly traded forprofit incubators in the USA.

Table 1 Well known for-profit incubators in the USA and their sharply declining valuation

\begin{tabular}{lccccr}
\hline For-Profit Incubator & $9 / 17 / 99$ & $9 / 17 / 00$ & $9 / 17 / 01$ & $9 / 17 / 02$ & \multicolumn{1}{c}{ high } \\
\hline Cmgi (cmgi) & 40 & 37.75 & 1.13 & 0.45 & $163.22(1 / 3 / 00)$ \\
Internet Capital Group (icge) & 40.53 & 29.87 & 0.47 & 0.22 & $200(1 / 3 / 00)$ \\
divine interVentures (dvin) & N/A & 6.75 & 0.80 & 2.67 & $10.87(7 / 14 / 00)$ \\
Safeguard Scientifics (sfe) & 23.73 & 27.43 & 2.22 & 1.33 & $98.5(3 / 17 / 00)$ \\
\hline
\end{tabular}

Corporate 'intra-ventures' or 'new initiative groups' are another form that for-profit incubators assume. During the past few years, large corporations have developed several models of incubation. Some (Intel, HP, Dell to name a few) have set up corporate venture funds that invest in start-ups outside the corporate walls. Others, like Samsung, spin off technology teams to be incubated offsite. Still others like UPS, Panasonic, Adobe, Ford, Lucent, and Trilogy have developed more traditional incubators. Trilogy-a privately-held Austin, TX-based software company-operates Trilogy University twice a year into which it brings 150-250 recruits to turn business plans into internet companies such as CarOrder.com, ApplianceOrder.com, CollegeHire.com, PCOrder.com. The company believes this unique entrepreneurial environment provides it with a competitive advantage in recruiting and retaining engineering talent. Consultancy companies and venture capitalists (Austin Ventures, Benchmark Capital, and Kleiner Perkins Caufield and Byers) have also entered the incubator fray as well.

The authors believe that, in order to succeed in the future, for-profit incubators will have to:

1 balance the need to diversify holdings while developing sector-specific expertise

2 make decisions more in the best interest of the start-up client than the incubator and its funding owners

3 focus on providing value-added services, networks, and overall support

The recent explosion of for-profit technology-based business accelerators has been a challenge to the more traditional university-or community-based incubators. Consequently, the delivery of value-added services becomes a vital differentiator between successful and unsuccessful incubators. A recent NBIA report of the incubation industry identified typical services (by more than $75 \%$ of the respondents) offered by technology incubators:

- $\quad$ assistance with business basics

- marketing assistance

- accounting/financial management

- $\quad$ investor and strategic partner linkages

- networking activities

- links to higher educational institution

- conference rooms and other shared facilities

- $\quad$ shared administrative services. 
Among the premier technology incubators in the country (in terms of track record and industry recognition) are the Advanced Technology Development Centre associated with Georgia Tech in Atlanta; the Colorado Technology Incubator associated with Colorado University in Boulder; The Entrepreneurial Centre in Birmingham, Alabama; Renssalear Polytechnic Institute Incubator Centre in Troy, New York; the Software Business Cluster of San Jose; and the IC ${ }^{2}$ Institute's Austin Technology Incubator of The University of Texas at Austin. Because of the authors' association with the latter, the rest of this chapter will consist of a case study of that incubator program.

Figure 1 Basic components of US Technology Incubators

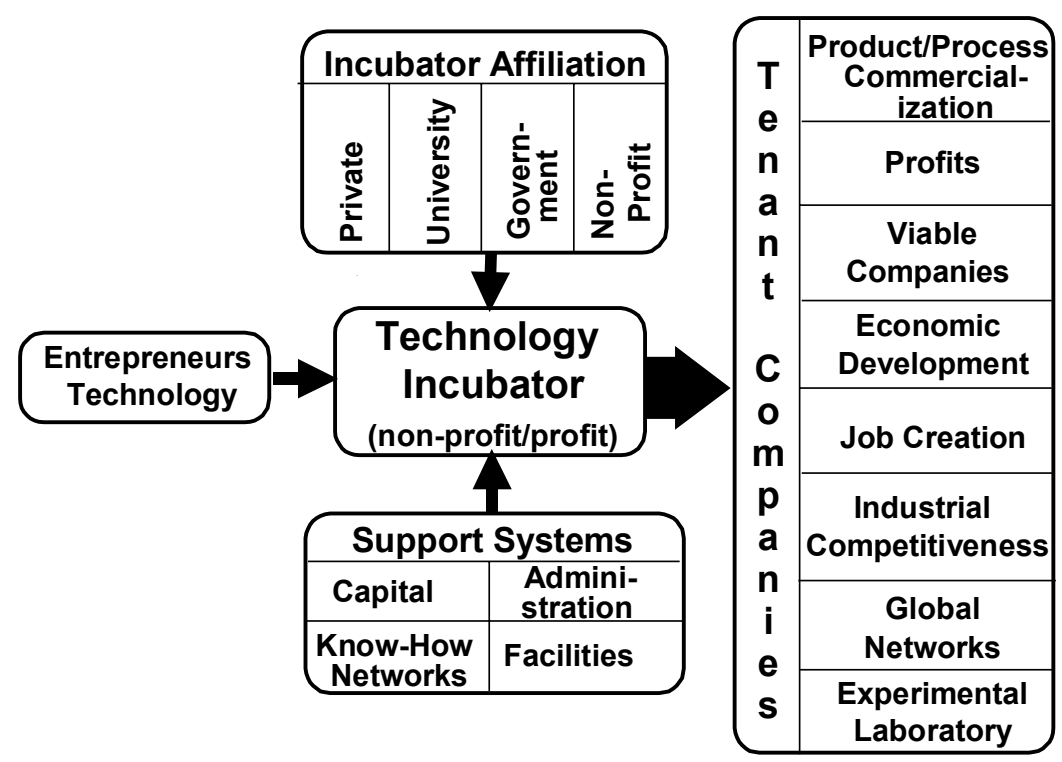

\section{The Austin Technology Incubator}

The Austin Technology Incubator (ATI) was founded by the $\mathrm{IC}^{2}$ Institute, The University of Texas at Austin in 1989 [2]. Austin was an emerging technology centre with the successful recruitment of major divisions of IBM, Motorola, and Advanced Micro Devices and after winning a major national competition for MCC (The Microelectronics and Computer Technology Corporation) in 1983, major research divisions of 3M in 1984, and SEMATECH in 1987 [3].

By late 1989, Austin became mired in a severe recession caused by sharply declining oil prices and a major Saving and Loan scandal that precipitated the bankruptcies of many of Austin's developers. The city's commercial building vacancy rate was fourth highest in the nation and rental prices hit rock bottom. The depressed oil and gas industry contributed to the rising unemployment. Yet Texas's Capitol city had its advantages. It was a university town with The University of Texas at Austin's 50,000 students and 
major research activities; the world-class research facilities of IBM, Motorola, MCC, and Sematech provided career opportunities for a young and highly educated workforce; a high quality of life attracted increasing numbers of non-natives; and an increasingly motivated city leadership was diligently searching for tangible solutions to the region's economic woes signified most by its empty office space and high unemployment.

Into this context, ATI was formed by a coalition of university, government, and business leaders led by Kozmetsky. The City, the County, the Chamber of Commerce and Kozmetsky funded a three-year experiment to create wealth, generate jobs, diversify Austin's struggling economy, fill office space, and build an entrepreneurial infrastructure for the City. The experiment was a success with the recruitment of three promising technology start-ups: one from California, one from UT-Austin, and one from MCC. Over the years ATI has graduated 65 companies, created 2,850 jobs, launched five IPOs and 13 acquisitions. ATI has also won numerous awards including NBIA's highest award as Incubator of the Year and the prestigious Justin Morrill Award from the Technology Transfer Society; four of its companies have won NBIA incubator companies of the year awards. Indeed, ATI has served as an inspiration and model incubator for a number of incubation programs in the USA and worldwide.

Figure 2 Ten success factors for Technology Incubators

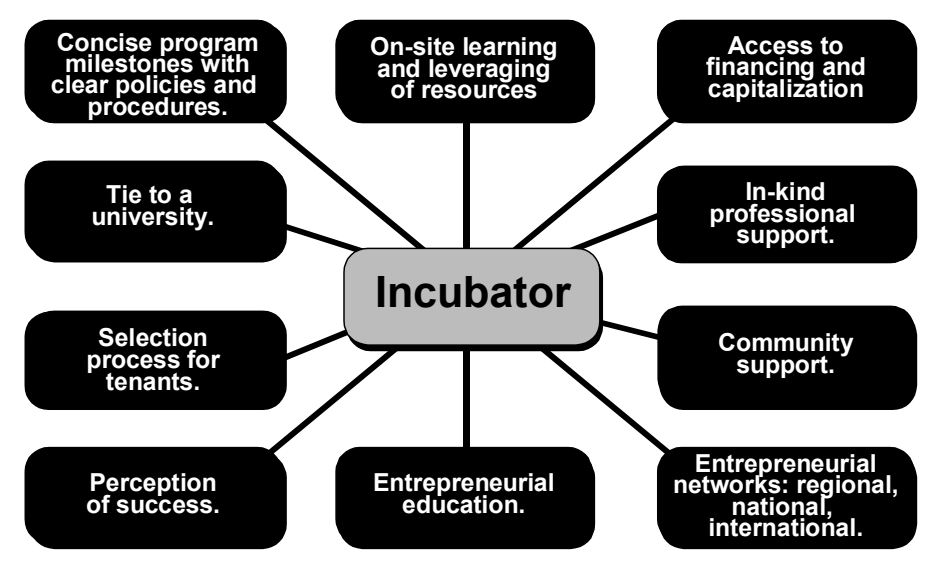

Over the past 12 years, several important lessons have been learned about successful business incubation. These lessons have been set forth in a recently developed training program that ATI has developed for incubation managers. Five success factors stand out as the most critical-to which we now turn our attention.

\subsection{Establish clear metrics of success}

Every incubator program must establish criteria of success against which it measures its performance. According to the NBIA, industry-wide priorities include creating jobs, creating new business, reducing business failures, accelerating business success, generating capital investment, and leveraging funds. Each incubator may have other domain-specific and local objectives such as encouraging minority or women 
entrepreneurs, revitalising a distressed neighbourhood, commercialising technologies, diversifying local economies, moving people from welfare to work, building or accelerating growth of a local industry, generating income and benefits for the sponsoring organisations, retaining businesses in the local community, enhancing a community's entrepreneurial climate, and so forth.

ATI clearly measures itself according to four criteria (business creation, wealth generation, innovation, and value to the university) and sets up processes and programs to ensure success in each area. Firstly, ATI seeks to stabilise highly promising, early-stage, high-risk high tech companies. To date more than 120 such companies have created 2,850 jobs and have a survival rate of better than $80 \%$ (versus the national average of $47 \%$ ).

Secondly, it focuses on helping its clients generate wealth for their stakeholders. In this regard, ATI also has been most successful. It numbers five IPOs and 13 acquisitions (including several in the $\$ 100$ million range) among its graduates. Cumulative company revenues exceed $\$ 1.2$ billion and, during the past four years alone, its resident and graduate companies have raised more than $\$ 300$ million in capital.

Thirdly, ATI seeks to bring innovative companies, products, and services to the market. Among its graduates are the first spinouts of UT, Sematech, and MCC respectively. It also sponsors the prestigious MootCorp international business plan competition and waives first year fees for the winning team from UT's Graduate School of Business.

The final measure of success for ATI is the value it returns to the university. ATI has become an entrepreneurial learning laboratory for faculty and students alike. It conducts commercialisation workshops, employs student interns from across the campus, and provides opportunities for faculty and students to work on projects in the incubator's start-up clients.

\subsection{Provide entrepreneurial leadership}

A critical attribute of successful incubation programs in the USA is an entrepreneurial staff. From director to receptionist, each must assume a can-do attitude, an ability to solve problems, a clear focus on results, and a willingness to work hard. An incubator's first director usually sets the tone for the future development and long-lasting success or failure of an incubator program.

ATI's success was ensured when Ms. Laura Kilcrease was selected to be its first director. Under her leadership the incubator exceeded its promises in terms of wealth and job creation. It became a model program within a few short years and obtained grants to help launch other incubators.

The patterns of entrepreneurial leadership were set through the various leadership transitions of ATI's history. Today the incubator is remaking itself into a technology commercialisation engine for not only the local university and community, but also by being the first of ten US incubators to form the Clean Energy Incubator Alliance in partnership with the National Renewable Energy Labs of the US Department of Energy. In its first year, Director Richard Amato has acted as a catalyst to generate five startups and solidify Austin's CEI community. 


\subsection{Develop service delivery system that delivers on behalf of client companies}

All incubators are service organisations. Whatever services it offers - from facilities to partner networks to funding to education and training - an incubator must measure itself according to two standards. It must design value-added services that client companies need and deliver those services in a consistent, timely, and excellent fashion. Only in so doing does the incubator actualise its potential to add value to its member companies.

Figure 3 Benefits of technology incubators

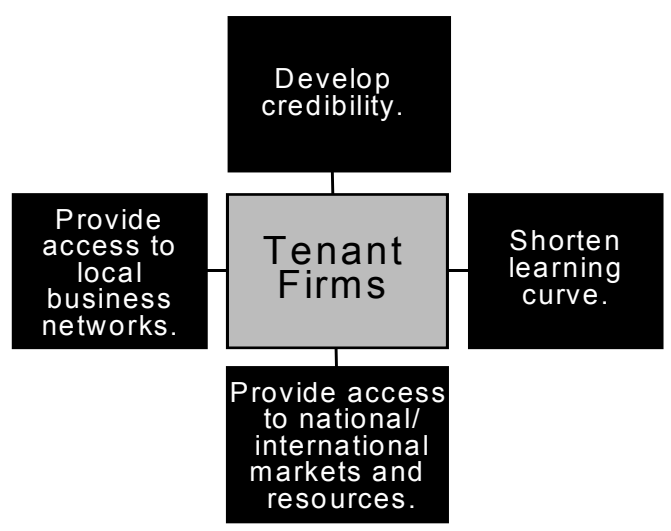

ATI provides infrastructure, operational, and strategic support services to its client companies for which it receives both market rate service fees and a $1 \%$ equity participation in the company. ATI's Assistant Director, Mr. Wes Cole, has created a Guide to Members Services that all new companies receive upon admission to ATI. The general service model is graphically represented below in Figure 4.

Strategic services include working with the company to perfect its business plan, executive summary, PowerPoint presentation, and elevator pitch. ATI also connects companies to mentors, advisory teams, and potential board of directors candidates. ATI director staff also work with companies to think through such things as its business model, its marketing strategy, its funding approach, its intellectual property strategy, and its product development.

Operational services include day-to-day issues such as financial management, human resources, marketing and public relations, and so forth. The incubator has developed a strong network of professional service providers that often offer preferred rates to incubator clients. ATI also uses its many student interns to provide valuable assistance to the start-up companies.

Infrastructure services refer to things like space, furniture, high-speed internet access, mail delivery, conference rooms, telephone service, shared services, and on-site amenities like a cafeteria, exercise facility, and so forth. These facility-related benefits allow clients to concentrate more time and attention on the matters of product development and business strategy rather than on the myriad time-consuming, but unproductive, necessities of doing business. 
The key is not to have a fancy model, but to be absolutely committed to designing valuable services that the companies will want and to execute the delivery of those services with great care and competence.

Figure 4 ATI Service delivery system model

\section{Strategic}

- CEO Mentors

- Advisory Review Panels
- Business communications

- Business plan development

\section{Operational}

$\begin{array}{llll}\text { Finance } & \text { HR } & \text { Mktg \& PR } \\ \text { - Funding } & \bullet \text { Benefits } & \bullet \text { Inhouse PR } \\ \text { - Accounting } & \bullet \text { Recruiting } & \bullet \text { Mkt research } \\ \text { - Banking } & \bullet \begin{array}{l}\text { Online } \\ \text { resume } \\ \text { bank }\end{array} & \bullet \text { Press contacts }\end{array}$

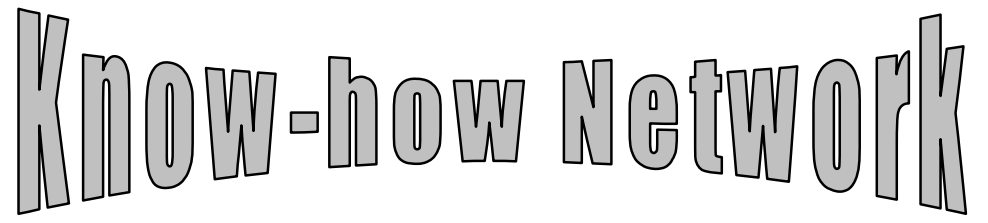

\section{Infrastructure}

- Flexible space

- Internet \& Telecom
- Shared services

- Conference space

\subsection{Develop a workable selection process}

Selecting companies is perhaps the most important consideration that sets apart one incubator from another. The selection process needs to be rational, well communicated, appropriate to the mission and context of the incubator, and flexible enough to allow for exceptions in unusual situations. Specific product and business criteria should govern the companies allowed in and those kept out. Each of the various stages (application, recruitment, due diligence, selection, induction, and orientation) requires extreme attention to detail. Adequate databases must be kept; records of agreements must be archived; process automation cannot take the place of human interaction. 
ATI requires both written and oral materials from those who apply because both sets indicate what kind of entrepreneurs are applying. The written materials (business plan and/or executive summary) show the quality of thought put into the business and the depth of domain knowledge the team may have. The verbal presentation, in the form of a PowerPoint presentation, provides an opportunity to meet the team and observe what challenges lie ahead in terms of creating and communicating the corporate vision and sales materials.

ATI also employs both an internal and external review process. The internal process is described in the previous paragraph. The external process involves taking the company forward to present before a panel of 6-15 outstanding investors, entrepreneurs and service professionals from the community. This guarantees that the company will receive a fair hearing of their business. The external panels also provide a way for ATI to connect to the community and provide potential alliances between the presenting company and the audience member.

Whatever process and criteria the incubator decides upon, selecting companies is a critical success factor. Often the success of the incubator lies as much in the selection of promising companies as in the development of the companies selected.

\subsection{Ensure access to capital on behalf of the companies}

Most technology companies rely on other peoples' money to build their business. A bootstrap strategy can take a company only so far. One of the primary values of the incubator is to help the client company acquire adequate financing. This can be done either through an incubator investment fund or referrals to outside funding organisations. External financing can take the form of angel investment, venture capital, strategic corporate investment, debt financing, government grants, and so forth.

In 2000, Austin, Texas had a robust capital environment of more than 100 angels, 30+ venture capital firms, and several banks that understand venture investment. However, in 1989 the city had only a few angels, a handful of venture firms, and no banks that undertook venture financing. ATI addressed the problem of lack of seed capital by starting The Texas Capital Network (since shorted to The Capital Network). TCN, as it is known, conducts venture capital conferences, introduces entrepreneurs to angel investors through regular monthly meetings, and conducts educational programs for investors and technology entrepreneurs alike.

ATI helps its client companies understand what it takes to attract venture financing, helps them develop their presentation materials, and makes introductions and referrals to appropriate sources of capital.

\section{Conclusion}

Incubators provide a proven economic development tool for their communities. Since 1980 , incubated companies have created more than 250,000 jobs. These jobs have increased the tax base, occupied additional commercial real estate space, contributed to the local business infrastructure, and lead to additional job creation in other sectors. 
Table 2 ATI Metrics (1989-2000)

\begin{tabular}{|c|c|c|c|c|c|c|c|c|}
\hline & 1989 & 1990 & 1992 & 1994 & 1996 & 1998 & 2000 & total \\
\hline $\begin{array}{l}\text { Revenue sales } \\
\text { (\$M USD) }\end{array}$ & $\$ 0$ & 6 & 26 & 60 & 132 & 200 & 281 & $\$ 1,250$ \\
\hline $\begin{array}{l}\text { FT jobs } \\
\text { created } \\
\text { (cumulative) }\end{array}$ & 87 & 239 & 435 & 700 & 1287 & 1750 & 2850 & 2850 \\
\hline $\begin{array}{l}\text { Graduates } \\
\text { (cumulative) }\end{array}$ & 0 & 2 & 8 & 20 & 33 & 50 & 65 & 65 \\
\hline $\begin{array}{l}\text { real estate } \\
\left(150 \mathrm{ft}^{2} /\right. \\
\text { employee) }\end{array}$ & 13050 & 35850 & 65250 & 105000 & 193050 & 262500 & 427500 & 427500 \\
\hline $\begin{array}{l}\text { jobs with } 2.5 \\
\text { multiplier }\end{array}$ & 217.5 & 597.5 & 1088 & 1750 & 3217.5 & 4375 & 7125 & 7125 \\
\hline $\begin{array}{l}\text { revenues with } \\
2.1 \text { multiplier }\end{array}$ & $\$ 0.0$ & $\$ 12.6$ & $\$ 54.6$ & $\$ 126.0$ & $\$ 277.2$ & $\$ 420.0$ & $\$ 590.1$ & $\$ 2,625.0$ \\
\hline
\end{tabular}

ATI's success, for example, has resulted in significant impact on the local economy. In large measure, ATI served as a catalyst for Austin's economic recovery in the 1990s by developing an entrepreneurial support infrastructure [4], expanding the region's tax revenues [5], and increasing demand for commercial office space [6].

For more than twenty years, business incubation has proven to be a flexible tool adopted by universities, local governments, and for-profit businesses to develop diverse industry sectors in urban, suburban and rural areas to create jobs, wealth, and other economic benefits. As the industry matures, novel methods of incubation will continue to emerge that strengthen the models currently in place and bring about even greater value to the stakeholders and communities that incubators serve.

\section{Notes}

1 The authors are indebted to various NBIA publications and website, www.nbia.org, for many of these introductory details.

2 Dr. George Kozmetsky was the champion for ATI and it was a natural extension of his educational and business background. Kozmetsky had emigrated to the USA as a young boy in the 1930's. He grew up in Seattle and pursued his education at The University of Washington and a PhD at Harvard. After teaching economics a few years at Carnegie Mellon University, Kozmetsky moved to California to begin his business career first at Hughes Aircraft and then Litton Industries. In 1958 he co-founded Teledyne Corporation and in six short years became a multi-millionaire. In 1966 he left the business world to become Dean of The College and Graduate School of Business, University of Texas at Austin. During his 16-year tenure as Dean he transformed the college into a program of excellence and set it on the path to become one of the elite public business schools in the nation. In 1977 he founded the IC ${ }^{2}$ (Innovation, Creativity, Capital) Institute at the University, a centre of action research on entrepreneurship, technology commercialisation, and constructive forms of capitalism.

3 MCC was the first for-profit R\&D Consortium formed in the USA and it focused on software R\&D. SEMATECH was another major consortium that targeted R\&D in the semiconductor industry. Both these consortia recruited some of the best research and technical talent in the USA to Austin. 
4 ATI helped found The Capital Network and the Austin Software Council. It also spurred increased local demand for venture capital firms, high tech banks, accounting firms, law firms, and other entrepreneurial support groups. For example, when ATI started in 1989 only a handful of venture capital organisations serviced the community and none serviced early stage companies seeking seed financing. Today more than 30 firms have a presence in Austin. Similar development has occurred in the accounting, law, banking, high tech associations and so forth.

5 The average high tech wage in Texas is about $\$ 60,000$ - approximately $75 \%$ higher than the average per capita job. ATI companies have created about 2,850 jobs yielding a year 2000 total of $\$ 171,000,000$ in wages. The $1 \%$ city tax on consumable spending would net the city $\$ 1,700,000$ if a person spent all his or her income on consumable goods. Since only about $60 \%$ is so spent, the net to the City is approximately $\$ 1,200,500$ this past year alone.

Another measure of the economic contribution is through property taxes. The average price of a home in Austin is about $\$ 150,000$; assuming an average 3\% property tax and that half the employees are homeowners, this computes to an additional $\$ 5,912,500$ of annual tax to the City.

6 Assuming that the average space allocated to an employee is $150 \mathrm{ft}^{2}$, ATI estimates that its graduate companies occupy more than $435,000 \mathrm{ft}^{2}$ of commercial real estate. Commercial space averages about $\$ 25 / \mathrm{ft}^{2}$ in Austin. This computes to almost $\$ 11$ million in real estate expenditures by ATI graduates.

\section{Bibliography}

Hansen, M.T. et al. (2000) 'Networked incubators: hothouses for the new economy', Harvard Business Review, Sept-Oct.

Kozmetsky, G., Gibson, D. and Kilcrease, L. (1993) 'NASA (Field Centre Based) technology commercialisation centers: value-added technology transfer for US competitive advantage', $I C^{2}$ Report.

Rice, M. and Matthews, J. (1995) Growing New Ventures-Creating New Jobs: Principles and Practices of Successful Business Incubation, Quorum Books.

Smilor, R., Gibson, D. and Kozmetsky, G. (1988) 'Creating the technopolis: high-technology development in Austin, TX', Journal of Business Venturing.

Tornatzky, L. et al. (1996) The Art and Craft of Technology Business Incubation, National Business Incubation Association (NBIA). 